\title{
Problems of mining the prospective coal- bearing areas in Donbas
}

\author{
Serhii Nehrii $^{*}$, Tetiana Nehrii $^{1}$, Leonid Bachurin $^{2}$, and Hanna Piskurska ${ }^{3}$ \\ ${ }^{1}$ Donetsk National Technical University, Department of Mineral Deposits Development, \\ 2 Shybankova Sq., 85300 Pokrovsk, Ukraine \\ ${ }^{2}$ Donetsk National Technical University, Department of Production Management and Occupational \\ Safety, 2 Shybankova Sq., 85300 Pokrovsk, Ukraine \\ ${ }^{3}$ Donetsk National Technical University, Department of Language Training, 2 Shybankova Sq., \\ 85300 Pokrovsk, Ukraine
}

\begin{abstract}
The prospective coal-bearing areas of Donbas in Ukraine have been identified. Their development will increase the energy security of Ukraine. It has been suggested that the development of these areas will involve mining the coal seams in a weak roof and floor environment, which are characterized by low compressive strength, lower density and a tendency to plastic deformations. The stability has been assessed of the rocks outcrop on the contour of mine roadways for mines operating in these areas. It has been determined that roof rocks in most of these mines belong to a range of groups from very unstable to moderately stable, and the bottom rocks are, in most cases, prone to swelling. This complicates the intensive prospective areas mining with the use of advanced technologies, as well as secondary support for retained goaf-side gateroads with limited yielding property. The mines have been determined, for which this issue is relevant when mining the seams with further increase in the depth. The mechanism of displacement in the secondary supports and has been exemplified and studied using the numerical method. The obtained results allowed us to substantiate the necessity of developing new technical solutions for the protection of gateroads under conditions of prospective Donbas areas.
\end{abstract}

\section{Introduction}

At present, coal seams are being mined under complex mining and geological conditions. In most mines, it is conditioned by increasing the depth of mining and weak lateral rocks. There is the largest number of deep mines in Donetsk-Makiivka, Pokrovsk, Lysychansk, Almaz-Marivka and Chystiakove-Snizhne coal fields. The operation of mines in these areas is marked by geomechanical problems associated with the maintenance of operational and safe working conditions due to the deterioration of mining conditions. In particular, there was a critical situation with the maintenance of gateroads under conditions of "Komsomolets Donbasu" mine, O.F. Zasiadko mine, M.M. Bazhanov mine,

\footnotetext{
*Corresponding author: serhii.nehrii@donntu.edu.ua
} 
"Shchehlovska-Hlyboka" mine, M.I. Kalinin mine, Komunarsk mine, L.I. Lutuhin mine, Shakhtoupravlinnia "Pokrovske", Kapitalna mine, Coal company "Krasnolymanska", etc.

The mine fund of the coal-bearing areas (Donetsk-Makiivka, Central, Amvrosiivka, Chystiakove-Snizhne, Luhansk, Krasnodonsk, Orihivka, Bokove-Khrustalne, DovzhanskRovenky) consists of old and worn-out mines which require reconstruction and rehabilitation. Most of the coal reserves in these areas have been exhausted. In addition, some of these areas have remained partially or completely in the temporarily occupied territory since 2014. Military operations, capture and robbery of the enterprises have led to mine closure, flooding, and loss of reserves. Therefore, in order to ensure Ukraine's energy security, it is necessary to increase coal extraction in operating mines and develop new prospective areas under complex mining and geological conditions. The urgent task is to identify the main problems of further mining in the Donbas coal-bearing areas.

\section{Main part}

In terms of density of coal reserves and its quality composition, the prospective areas are as follows: Petrykivka, Novomoskovsk, Lozivske, Pavlohrad-Petropavlivka, Southern Donbas, Pokrovsk, Northern Donbas (Starobilsk area), Lysychansk (Fig. 1). These areas are represented by $\mathrm{C}_{1}{ }^{3}, \mathrm{C}_{2}{ }^{1}, \mathrm{C}_{2}{ }^{3}, \mathrm{C}_{2}{ }^{5}, \mathrm{C}_{2}{ }^{6}, \mathrm{C}_{2}{ }^{7}$ and $\mathrm{C}_{3}{ }^{2}$ coal formations, including coal grades from $\mathrm{B}$ to $\mathrm{K}$ (Fig. 2). In the larger area, there are mostly $\mathrm{D}$ and $\mathrm{G}$ coal grades with a low metamorphic grade. These formations are characterized by flat coal seams with thickness from 0.6 to $2.5 \mathrm{~m}$ (the coal seams with thickness of less than $1.3 \mathrm{~m}$ are predominant) [1].

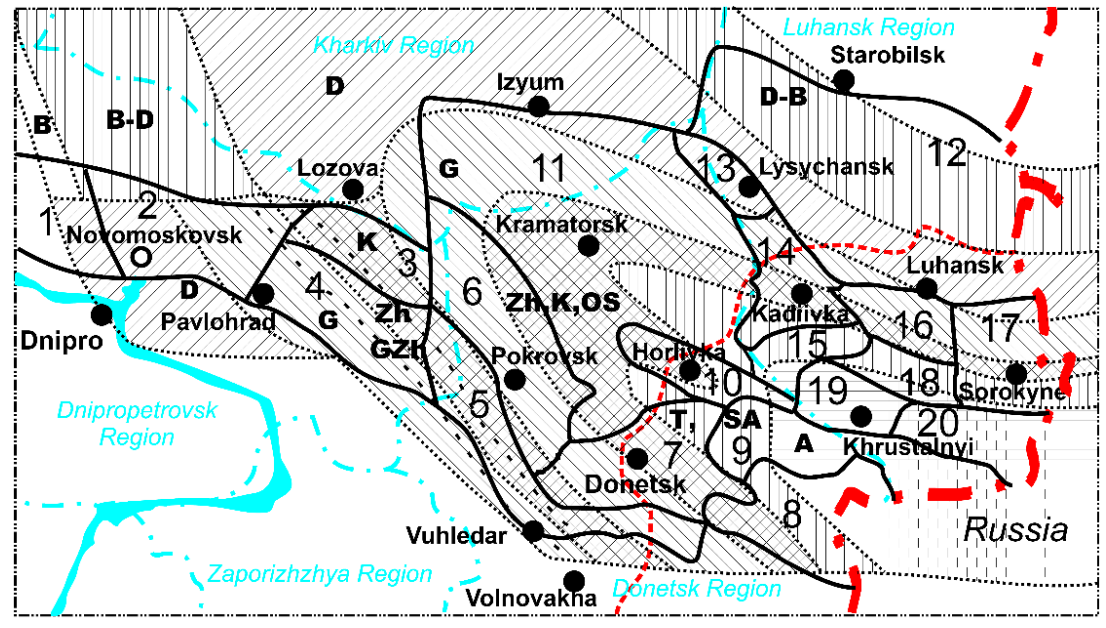

Fig. 1. Map of coal types distribution within the coal-bearing areas of the Donetsk basin in the territory of Ukraine (Symbols: 1-20 - coal-bearing areas of the Donetsk basin in the territory of Ukraine. 1 - Petrykivka, 2 - Novomoskovsk, 3 - Lozivka, 4 - Pavlohrad-Petropavlivka, 5 - Southern Donbas, 6 - Pokrovsk, 7 - Donetsk-Makiivka, 8-Amvrosiivka, 9-Chystiakove-Snizhne, 10 Central, 11 - North-Western outskirts of Donbas, 12 - Northern Donbas, 13 - Lysychansk, 14 Almaz-Marivka, 15 - Seleznivka, 16 - Luhansk, 17 - Krasnodonsk, 18 - Orihivka, 19 - BokoveKhrustalne, 20 - Dolzhansk-Rovenky; $\_-$the boundaries of coal-bearing areas; --- the boundary of the temporarily occupied territory; B...A - coal grades (B - brown coal, D - "high volatile, non-coking coals", G - "high volatile, weakly cooking coal", GZh - "gas-bold" (medium coking coal), $\mathrm{Zh}$ - "bold" (strongly coking coal), $\mathrm{K}$ - "coke" (prime coking coals), OS - "thin-caked" semi-soft coking coals (coking steams coals), T - "thin" (dry steam coals), SA - semi-anthracite, A anthracite); ......... - the boundaries of the coal types allocation zones). 
Rocks containing coal seams of a low metamorphic grade are characterized by low compressive strength [1], a lower density than high grade, high porosity of sandstones, and plastic properties of mudrocks. For example, mudrocks which belong to the D-grade coal area, are characterised by plastic claystones that swell on wetting; G-grade coal areas is characterized by rather plastic claystones [1]. This proves the fact that coal mining in prospective Donbas areas will involve mine workings in the weak lateral rocks, which may be one of the main problems.

Intensification of mining in these areas requires the use of advanced mining techniques and mine layouts, high-performance cutting equipment, etc.

Progressive longwall mining is based on Y-type gateroads layout, which provides coal extraction without protection pillars and stable-holes, by means of effective ventilation schemes of the longwall panels. These mining systems require maintenance of gateroads both in front and behind the longwall face, which presupposes the use of effective support technologies for gateroads, especially in situations of abutment loading. Thus, the gateroads are in a difficult geomechanical state due to complicated mining, geological and technical conditions.

Weak roof and floor environment does not yet indicate an unsatisfactory state of gateroads, since their stability depends not only on the rock strength, but on the depth of mine workings and other factors. The degree of unsatisfactory state can be determined by the criteria of rock resistance, which, as a rule, are used to assess the stability of the roof strata.

To determine the stability of roof rocks in single mine roadways, the criterion $\gamma H_{p} / R_{c}$ is used (where $\gamma$ is the overall density of overburden, $\mathrm{MH} / \mathrm{m}^{3}, H_{p}$ is the depth of the mine working, $\mathrm{m}, R_{c}$ is the uniaxial compressive strength of the surrounding rocks, MPa) [2]; and $H_{p} / R_{c}$ is used for the floor strata. The first criterion determines the stability of roof rocks outcrop, and the second - the propensity of the floor strata to extrusion and the scope of hard secondary supports applications. At values $H_{p} / R_{c} \geq 20,25$ and 15, it is recommended to take action to mitigate the swelling of floor strata, respectively in retained goaf-side gateroad, which is remained open for reuse [3]. This criterion has been developed in further work [4], where $H_{p} / R_{c}=15$ is a critical value, which determines the possibility of using hard secondary supports.

Depth of mine workings in the prospective Donbas coal-bearing areas vary from 225 to $1090 \mathrm{~m}$, and the compressive strength of rocks - from 5 to $216 \mathrm{MPa}$. Therefore, the roof rocks in most mines fall into categories from very unstable to medium-stable whereas the floor strata, in most cases, are unstable and prone to extrude under load or to swell. This is confirmed by the research results on the stability of mine roadways in underground coal mines, which are part of "DTEK Pavlohradvuhillia" PJSC [5]. According to this, the bottom rock dinting is $77 \%$ of all repair work in the gateroads, whereas re-supporting does not exceed $4 \%$ in total. At "DTEK Dobropilliavuhillia" LLC [6] the bottom dinting is from 69 to $84 \%$ of the length of mine roadways under repair, and at " $1 / 3$ Novohrodivka" mine [7] and SE Shakhtoupravlinnia "Pivdennodonbaske No. 1" [8,9] the proportion of the floor displacement in the roof and floor convergence is $65-70 \%$.

While evaluating the possibility of using hard secondary supports under such conditions, it is advisable to use Fig. 2, where the zoning criterion is $H_{p} / R_{c}=15$. When comparing the working conditions with the zones of effective use of hard secondary supports, we can conclude that the greater part of the conditions falls to the zone of ineffective use of these structures. But this question is the most relevant for "Kapitalna" mine, M.S. Surhai mine and those which are part of DTEK Shakhtoupravlinnia "Dobropilske", DTEK Shakhtoupravlinnia "Bilozerske" and "Lysychanskvuhillia" PJST. In the mines of Lozove and Pavlohrad-Petropavlovsk regions, the possibility of using such structures is particularly relevant at working depths of more than $500 \mathrm{~m}$. 


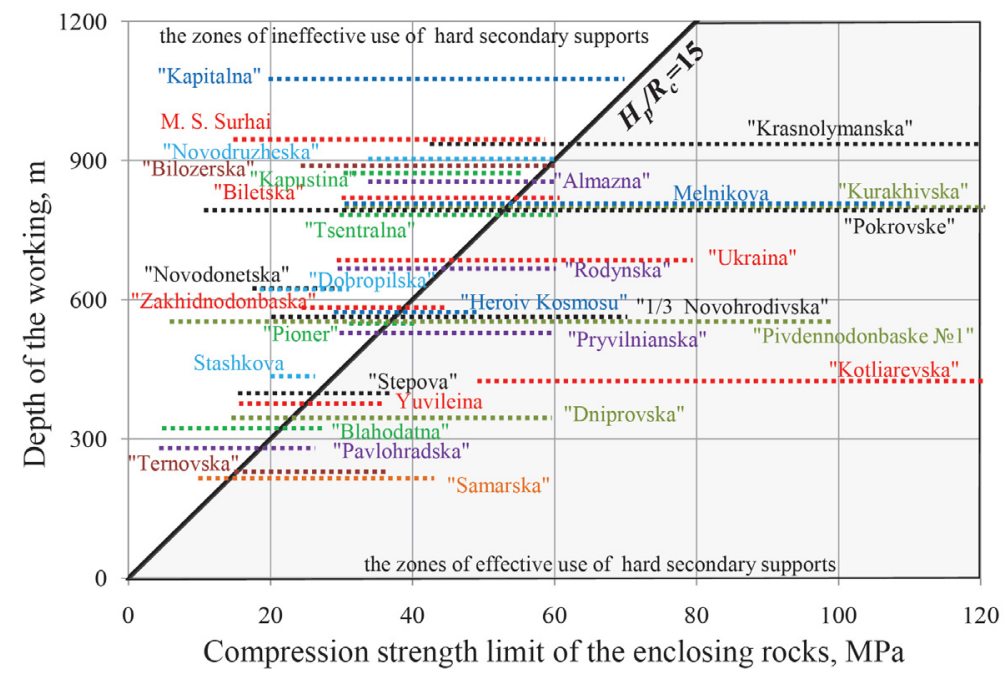

Fig. 2. Schedule on the appropriateness of hard security structures use in conditions of prospective mines in Donbas.

In such conditions, it is rather difficult to maintain retained goaf-side gateroads, since on the one hand there is a coal pillar, and on the other - a goaf (this situation is referred to as single sided abutment loading). Thus, the main task is to create the conditions for providing sufficient resistance when supporting the roof at the gateroad. It is achieved at the expense of secondary supports of limited yielding property, since the harder the secondary support is, the less convergence in the gateroads is [10]. But if the bottom rocks are weak, it is almost impossible, since secondary support works as punch, and the yield limitation is levelled off by their height reduction relative to the bottom surface. This mechanism can be investigated by the results of numerical simulation, which has a number of advantages over other methods, such as universalism, considering a large number of impact factors, low complexity of obtaining results in a relatively short period of time, absence of necessity for materials and special equipment, etc. [11].

Among the numerical methods for the study of geomechanical processes under the conditions of underground mining, the finite elements method (FEM) has become very popular, which contributed to the emergence of software complexes based on this method. These allow solving geomechanical problems with a wide array of parameters very quickly. The following packages are the most popular: ANSYS [12-14], Solid Works [14], PLAXIS [11, 15-19], FLAC3D [20-22] and PHASE-2 [23-25]. These software systems give almost identical results [30] but differ in the degree of complexity in constructing the model's geometry and in using different models of material behaviour when setting tasks.

The PLAXIS 2D package is used to simulate the process of compression the rocks that underlie the standing support, since it differs from its analogues by a simple user interface, high accuracy of calculations, and also by taking into account the nonlinearity of the discrete environment, which is the rock solid around the excavation and the standing support.

The study of the deformation mechanism in the rocks underlying the standing support has been carried out under conditions of maintaining the gateroads of the $c_{18}$ seam of Shakhtoupravlinnia "Pivdennodonbaske No. 1" mine. These gateroads are characteristic for the mines of prospective coal-bearing areas and reflect the main features of mining, geological and technical conditions of coal seams with unstable roof and floor strata [9]. In 
this seam gateroads are stabilised by pillars, chokes, packfillings and backfill walls. Its development is complicated not only by weak adjacent rocks, but also by the presence of tectonic disturbances and areas with excessive watering.

The problem has been solved in two-dimensional formulation, since the standing support and the solid under it are elongated in the plan and the stresses are distributed coplanar. For this purpose, a geometric model of a unit thickness has been constructed. It consists of rock layers of the immediate and main bottoms above which the standing support is located (Fig. 3).

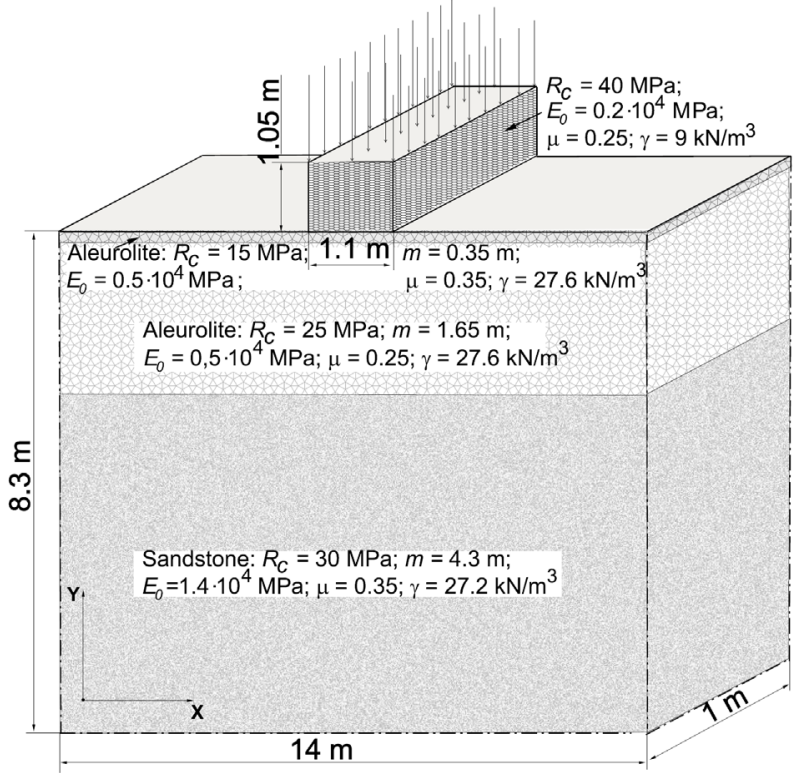

Fig. 3. The geometry of the standing support, located on the solid of bottom rocks $\left(R_{c}\right.$ is compressive strength, $m$ is layer thickness, $E_{0}$ is modulus of elasticity or general deformation, $\mu$ is coefficient of transverse deformation, $\gamma$ is volume weight).

Considering the boundary conditions, the parameters of the standing support and the problem under study, the following dimensions of the rock massive volume have been taken: height $-8.3 \mathrm{~m}$, width $-14 \mathrm{~m}$.

The standing support width load will be uneven, since the goaf-side loading is $1.5-1.6$ times more than the road-side loading [12]. This is explained by the fact that as a result of the stress redistribution in the solid around the retained goaf-side gateroad, a destruction zone is formed. It also involves formation of a break line between the main roof rocks and the untouched solid [27]. Behind the longwall face the roof rock strata are based on the standing support. Due to the suitability of the standing support to its possible punching into floor, the surrounding rocks are rotated around the mine working at an angle $\varphi\left(\varphi=3-9^{\circ}\right)$, which leads to the formation of an asymmetric standing support load against the weight of the hanging rocks (Fig. 4). Thus, the maximum displacement of roof rocks above the standing support $U_{\max }$ is on the goaf-side.

The peculiarities of the standing support intrusion into the bottom depend on various factors, which include composition and physical and mechanical properties of the adjacent rocks, the seam slope angle, the peculiarities of the gateroad layout, the way of the roof control, the speed of extraction. But it is quite difficult to consider all these factors. Therefore, it is necessary to make certain reservations and use averaged data to assess the impact of the standing support, which is a pressure concentrator, on the floor. We restrict ourselves to the following parameters: the load value, the bottom rock strength, the 
hardness of the standing support, its width and height, the thickness and strength of the bottom rock strata.

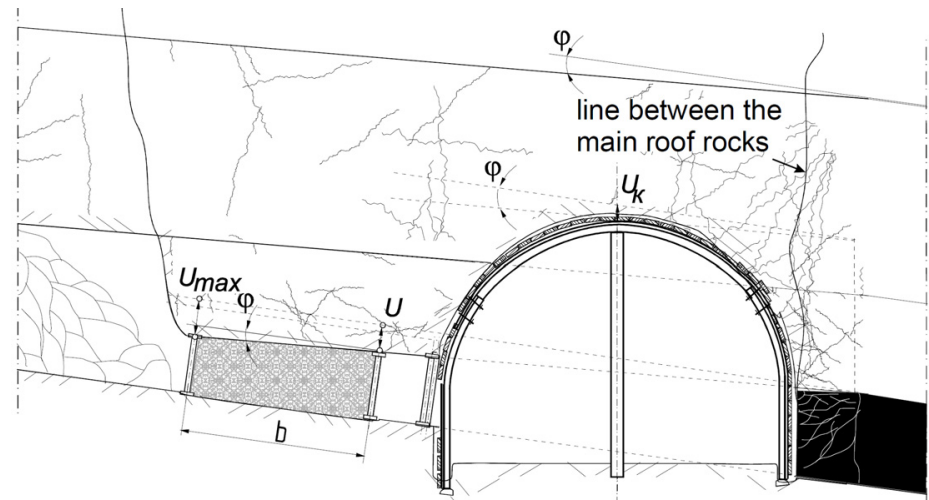

Fig. 4. Scheme of the roof rocks displacement above the standing support.

The main physical and mechanical characteristics of the material specified in PLAXIS 2D are the internal friction angle, the cohesion, specific weight, Young's modulus, Poisson's ratio, and dilatancy angle. As seen, the rock strength is not considered, but this disadvantage can be eliminated by using the formula

$$
R=\frac{2 C}{\operatorname{tg}\left(45^{\circ}-\frac{\rho}{2}\right)},
$$

where $C$ is the cohesion, $\mathrm{MPa} ; R$ is the uniaxial compressive strength, $\mathrm{MPa} ; \rho$ is the internal friction angle, degrees.

The Mohr-Coulomb elastic-plastic model is used to implement the non-linear relationship between confinement and stress. Since the effect of the standing support on the bottom rocks has been considered, the regime of the given displacements has been adopted. For this purpose, the research results in the maingate 11 of the western longwall development panel of the $c_{18}$ seam at Shakhtoupravlinnia "Pivdennodonbaske No. 1" mine [9] have been taken as input data. It was protected by continuous standing supports of $b$ width equal to $1.1 \mathrm{~m}$. The maximum roof rock displacement above the $U_{\max }$ standing support made up $41 \%$ of the extracted seam thickness and equalled $0.43 \mathrm{~m}$. They occurred on the upper platform of the standing support (Fig. 4) on the left side, which is part of the goaf. On the opposite side (right), which is on the boundary line with the gateroad, the displacements have been determined as $U_{\max }-b \operatorname{tg} \varphi$ and amounted to $0.31 \mathrm{~m}$.

The implementation of the finite element model (Fig. 5) constructed under conditions of $\mathrm{c}_{18}$ seam allows us to obtain the results (Fig. 6), which indicate that under such conditions secondary support with strength greater than the bottom rock starting to punch floor. In general, it negatively affects the displacement of roof rocks and the state of the supported gateroads. With the rock subsidence over the standing support $(0.43 \mathrm{~m})$, its flexibility proportion was $79 \%(0.34 \mathrm{~m})$, and the proportion of its punching into floor strata was $21 \%$ $(0.09 \mathrm{~m})$. In this case, the ratio of the maximum value of the rock compression $(0.21 \mathrm{~m})$ to the value of standing support yield $(0.09 \mathrm{~m})$ was 2.3 . Thus, the standing support yield is the cause of punching weak bottom rocks into the worked-out area and a slight yield of the structure leads to significant rock displacement into the mine working. 

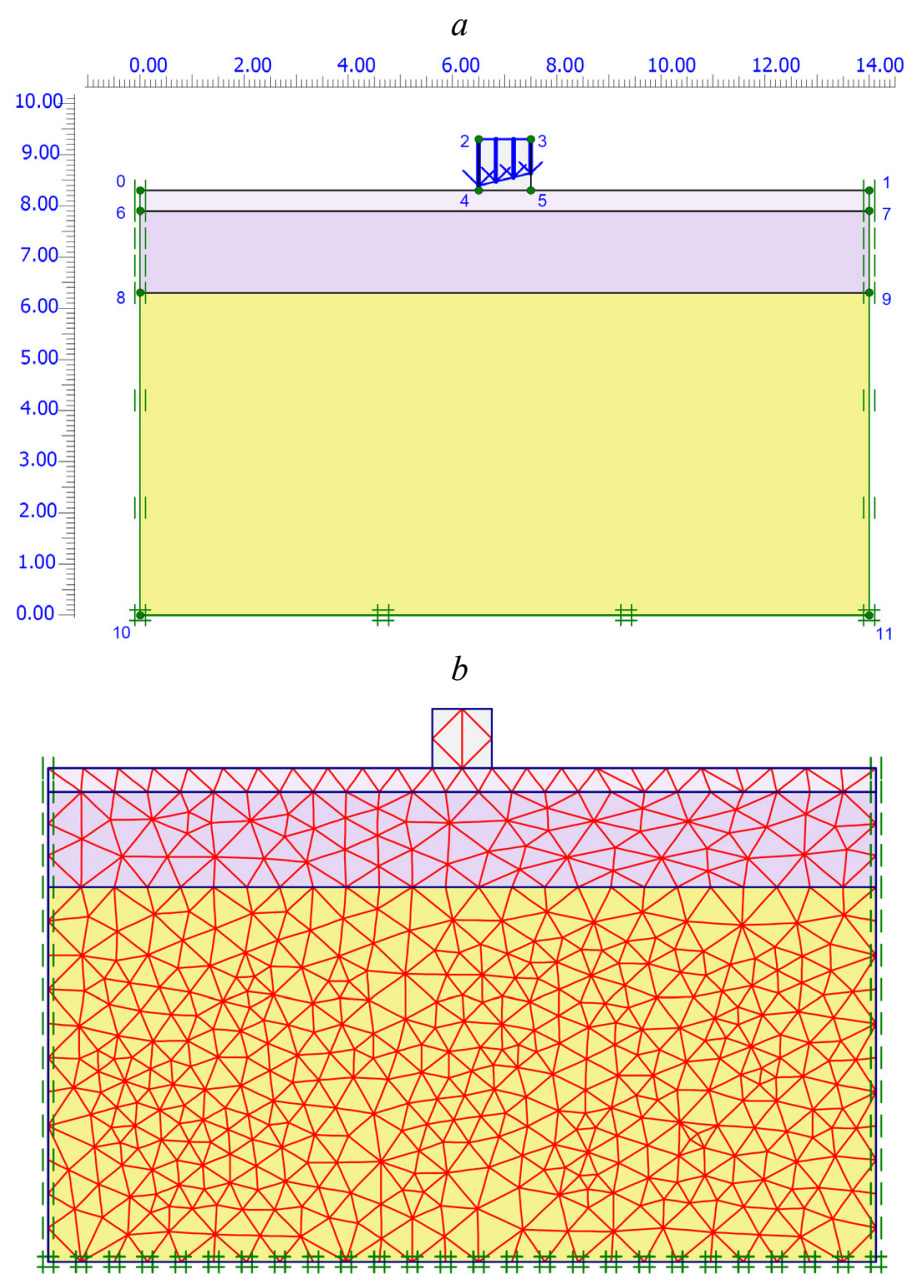

Fig. 5. Geometric model in the data-entry window (a) and finite element grid (b).

In such conditions, the use of hard structures will be complicated. Since the condition for their use is $H_{p} / R_{c} \leq 15$ (Fig. 2), it is necessary to ensure strengthening of the bottom rock. Another solution could be to develop new technologies that would consider the mechanism of interaction between the secondary support and the bottom rocks. In our opinion, effective resource-saving secondary support for the conditions of unstable adjacent rocks should be developed. These structures would be constructed of cheap materials. Due to special structural features (change of form, application of reinforcing elements, etc.) they could influence the excavation contour and provide working tension redistribution. An example of such technologies may be stabilisation of retained gateroads by isolated standing support of rectangular or trapezoidal shapes [11, 12, 29], with the compensating bags (packfillings) between them, combined secondary support with hard and flexible elements [30 - 32], etc. In order to substantiate their use in the conditions of prospective mines in Donbas and justify rational parameters of these technologies, further research is required. 


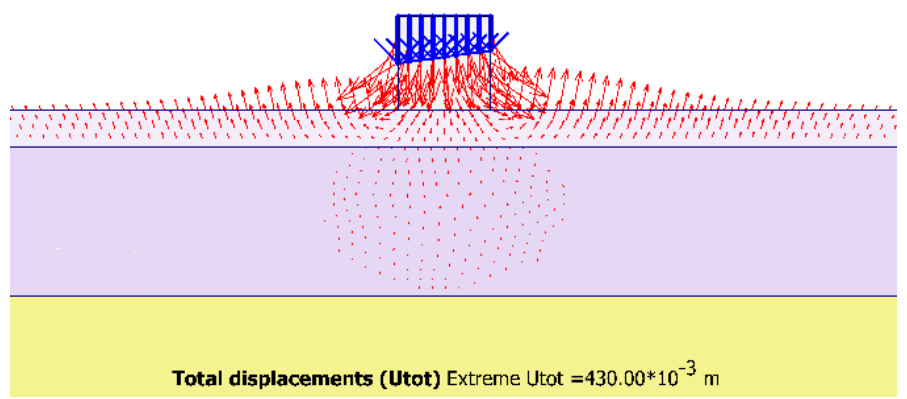

$b$

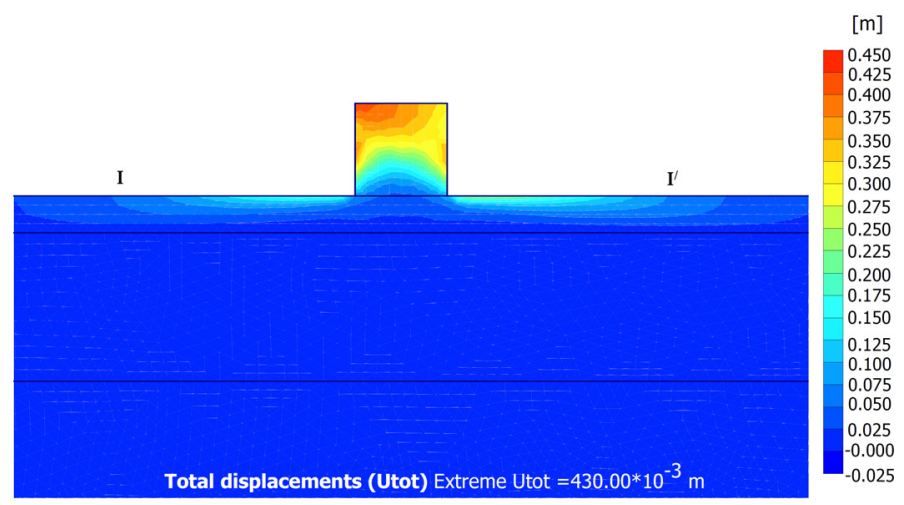

$c$

$\left.\begin{array}{llllllllllll}2.00 & 3.00 & 4.00 & 5.00 & 6.00 & 7.00 & 8.00 & 9.00 & 10.00 & 11.00 & 12.00 & 13.00\end{array}\right]$

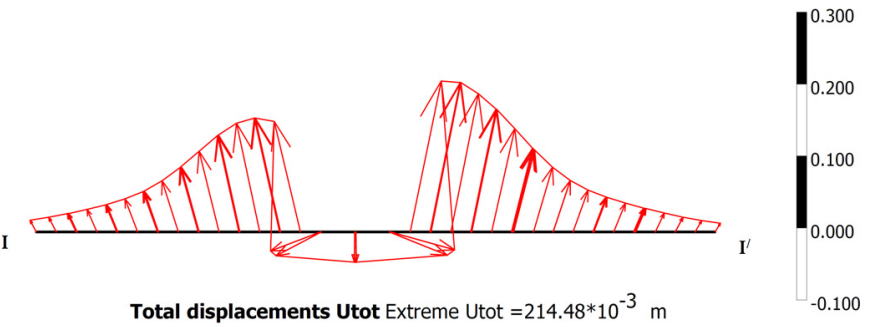

Fig. 6. The results of calculating total displacements in the standing support and the weak bottom rocks according to the findings of numerical simulation (a - displacement vectors distribution, $b-$ displacement isolines distribution, $\mathrm{c}$-displacement vectors directions along the line I-I' on the bottom rock surface).

\section{Conclusion}

The research findings are as follows:

- to ensure energy security of Ukraine, it is necessary to increase coal production in prospective regions of Donbas: Petrykivka, Novomoskovsk, Lozivske, PavlohradPetropavlivka, Southern Donbas, Pokrovsk, Northern Donbas, Lysychansk;

- the development of coal reserves in these areas will be accompanied by complex of mining and geological conditions and maintenance of mine roadways in unstable adjacent 
rocks;

- the main task when supporting retained goaf-side gateroads is to create conditions for ensuring sufficient resistance to rock convergence by secondary support with limited yielding property;

- in weak bottom rocks it will be difficult to use secondary support with limited yielding property, as these structures will be punched into the floor, which will lead to subsidence and extrusion of weak foundation strata. This will negatively affect the condition of the supported gateroad. This requires the application of technical solutions aimed at eliminating the punching of secondary support into the floor;

- to date, numerous attempts to create effective resource-saving secondary supports for retained goaf-side gateroads in the conditions of weak bottom rocks have been unsuccessful. Therefore, the development of new technologies is urgent for the prospective Donbas mines.

This work was carried out within the framework of the project "Improvement of ways to increase the stability of mine workings in deep mines" (State registration No.0117U004316). The authors appreciate the help of the head of Department of Geology, Mineral Exploration and Processing, Donetsk National Technical University, Professor Viktor Alokhin in consultations and assistance in conducting research.

\section{References}

1. Lazarenko, E.K., Panov, B.S., \& Gruba, V.I. (1975). Mineralogiya Donetskogo basseyna (part I). Kyiv: Naukova dumka.

2. Zaslavskiy, Yu.Z., \& Druzhko, E.B. (1989). Novye vidy krepi gornykh vyrabotok. Moskva: Nedra.

3. Ukazaniya po ratsionalnomu raspolozheniyu, okhrane podderzhaniyu gornykh vyrabotok na ugolnykh shakhtakh SSSR (1986). Leningrad, VNIMI.

4. Timokhin, A.N. (1993). Obosnovanie parametrov i razrabotka podatlivykh opor dlya okhrany povtorno ispolzuemykh vyrabotok. Ph.D. VNIMI.

5. Smirnov, A.V. (2018). Geomekhanicheskoe obosnovanie bezopasnoy tekhnologii podzemnoy dobychi uglya v neustoychivykh vmeshchayushchikh porodakh. Dr. YURGPU (NPI).

6. Kuzhel, S.V. (2000). Obgruntuvannia sposobu pidvyshchennia stiikosti kamer velykoho poperechnoho pererizu u vuhilnykh shakhtakh: Ph.D. NHA Ukrainy.

7. Logunova, A.O. (2016). Geomekhanicheskoe obosnovanie tselesoobraznosti povtornogo ispolzovaniya podgotovitelnykh vyrabotok ugolnykh shakht. Ph.D. NMU.

8. Solodyankin A.V., Grigoryev, A.E., Khalimendik, A.V., \& Mashurka, S.V. (2015). Shakhtnye issledovaniya geomekhanicheskikh protsessov v okrestnosti uchastkovykh vyrabotok GP "Shakhtoupravlenie "Yuzhnodonbasskoe №1". Geo-Technical Mechanics, (123), 87-98.

9. Nehrii, S., Sakhno, S., Sakhno, I., \& Nehrii, T. (2018). Analyzing kinetics of deformation of boundary rocks of mine workings. Mining of Mineral Deposits, 12(4), 115-123. https://doi.org/10.15407/mining12.04.115

10. Farmer, I. (1985). Coal mine structures. Chapman and Hall. London. http://doi:10.1007/978-94009-4834-1

11. Karpov, G.N., \& Leisle, A.V. (2017). Qualitative assessment of strain stress distribution of rock massif in the vicinity of pre-driven recovery room. Journal of Industrial Pollution Control, 33(1), 840-846.

12. Kasyan, N.N., Mokrienko, V.N., \& Sakhno, I.G. (2012). Opytno-promyshlennaya proverka sposoba okhrany vyrabotki zhestkimi sooruzheniyami s kompensatsionnymi polostyami $\mathrm{v}$ usloviyakh shakhty "Shcheglovskaya-Glubokaya". Naukovyi Visnyk Natsionalnoho Hirnychoho Universytetu, (6), 30-36. 
13. Nehrii, S., \& Nehrii, T. (2017). Conditions of use trapezoidal security installations. Journal of Donetsk Mining Institute, 2(41), 7-18. https://doi.org/10.31474/1999-981x-2017-2-7-18

14. Nehrii, S., Nehrii, T., \& Piskurska, H. (2018). Physical simulation of integrated protective structures. E3S Web of Conferences, (60), 00038. https://doi.org/10.1051/e3sconf/20186000038

15. Medianyk, V.Iu. (2009). Formuvannia sklepinnia rivnovahy nad pidhotovchoiu vyrobkoiu za dopomohoiu smuh zminnoi zhorstkosti - yak sposib ii okhorony i bezremontnoi pidtrymky. GeoTechnical Mechanics, (81), 173-183.

16. Bulat, A.F., Usachenko, B.M., Sergienko, V.N., Ilyashov, M.A., Yaytsov, A.A., \& Agofonov, A.V. (2009). Poryadok primeneniya "Tekhnologicheskogo reglamenta podderzhaniya povtorno ispolzuemykh vyemochnykh shtrekov kombinirovannymi okhrannymi sistemami". GeoTechnical Mechanics, (83), 3-13.

17. Sdvizhkova, Ye.A., Babets, D.V., \& Smirnov, A.V. (2014). Support loading of assembly chamber in terms of Western Donbas plough longwall. Naukovyi Visnyk Natsionalnoho Hirnychoho Universytetu, (5). 26-32.

18. Sakhno, I.G. (2015). Nauchnye osnovy upravleniya sostoyaniem gornykh porod nevzryvchatymi razrushayushchimi smesyami pri podzemnoy razrabotke mestorozhdeniy. Dr. DonNTU.

19. Litvinskiy, G.G., \& Gayko, G.I. (2004). O zakonomernostyakh vzaimodeystviya krepi i massiva v podgotovitelnoy vyrabotke vblizi lavy. Geo-Technical Mechanics, (51), 18-23.

20. Nazymko, V., \& Griniov, V. (2016). Implementing FLAC3D model for simulating deformation mechanism of steel frame support set by actual profile. Mining of Mineral Deposits, 10(1), 57-62. http://dx.doi.org/10.15407/mining10.01.057

21. Kovalevs'ka, I., Symanovych, G., \& Fomychov, V. (2013). Research of stress-strain state of cracked coal-containing massif near-the-working area using finite elements technique. Annual Scientific-Technical Colletion - Mining of Mineral Deposits, 159-163. https://doi.org/10.1201/b16354-28

22. Bondarenko, V., Symanovych, H., Kicki, J., Barabash, M., \& Salieiev, I. (2019). The influence of rigidity of the collapsed roof rocks in the mined-out space on the state of the preparatory mine workings. Mining of Mineral Deposits, 13(2), 27-33. https://doi.org/10.33271/mining13.02.027

23. Zingano, A., \& Weiss, A. (2019). Subsidence over room and pillar retreat mining in a low coal seam. International Journal of Mining Science and Technology, 29(1), 51-57. https://doi.org/10.1016/j.ijmst.2018.11.022

24. Ghosh, G.N., Behera, S.K., Prabhal K. Mandal, Plashant, Phanil K. Mandal, Das, A.J., \& Singh, P.K. (2017). Development of technology for extraction of locked up coal using artificial pillars. NexGen Technologies for Mining and Fuel Industries, (1), 417-424.

25. Aksoy, C.O. \& G. Gulsev Uyar. (2017). Non-deformable support system in swelling and squeezing rocks. Rock Mechanics and Engineering, (4), 179-203.

26. Das, A.J., Mandal, P.K., Ghosh, C.N., \& Sinha, A. (2017). Extraction of locked-up coal by strengthening of rib pillars with FRP - A comparative study through numerical modelling. International Journal of Mining Science and Technology, 27(2), 261-267. https://doi.org/10.1016/j.ijmst.2017.01.024

27. Małkowski, P., \& Ostrowski, Ł. (2014). Wpływ właściwości mechanicznych skał otaczających wyrobisko korytarzowe na zjawisko wypiętrzania spągu. Przeglad Gorniczy, (12), 78-90.

28. Zhang, Z., Shimada, H., Sasaoka, T., \& Hamanaka, A. (2017). Stability Control of Retained Goaf-Side Gateroad under Different Roof Conditions in Deep Underground Y Type Longwall Mining. Sustainability, 9(10), 1671. https://doi.org/10.3390/su9101671

29. Radouane, N., Boukelloul, M., \& Fredj, M. (2015). Stability Analysis of Underground Mining and their Application on the Mine Chaabte El Hamra, Algeria. Procedia Earth and Planetary Science, (15), 237-243. https://doi.org/10.1016/j.proeps.2015.08.058

30. Bock, S. (2015). New open-source ANSYS-SolidWorks-FLAC3D geometry conversion $\begin{array}{llll}\text { programs. Journal of Sustainable Mining, 14(3), 124-132. } & \end{array}$ http://dx.doi.org/10.1016/j.jsm.2015.11.002 
31. Solodiankin, O.V., Dudka, I.V., Tereshchuk, R.M., \& Hryhoriev, O.E. (2017). Okhorona pidhotovchykh vyrobok, shcho vykorystovuiut povtorno, $v$ umovakh antratsytovykh shakht. Dnipro: Nationalnyi hirnychyi universytet.

32. Houari, N.El., Allal, M.A., \& N. Abou Bekr (2011). Numerical Simulation of the Mechanical Response of the Tunnels in the Saturated Soils by Plaxis. Jordan Journal of Civil Engineering, 5(1), 9-31. 